A N N A L ES

UNIVERSITATIS MARIAE CURIE-SKŁODOWSKA

LUBLIN - POLONIA

VOL. LXII, 2

SECTIO G

2015

AGATA LUDERA-RUSZEL

\title{
Działania pozytywne jako instrument realizacji zasady równego traktowania kobiet i mężczyzn w zatrudnieniu
}

Positive Action as an Instrument for Implementing the Principle of Equal Treatment of Women and Men in Employment

\section{WSTĘP}

Prawo do równego traktowania jest podstawowym prawem człowieka. Jego emanacją jest prawo do równego traktowania w zatrudnieniu zaliczane do fundamentalnych praw socjalnych, uznane w dokumentach programowych oraz aktach prawnych Międzynarodowej Organizacji Pracy (MOP), Rady Europy, Organizacji Narodów Zjednoczonych (ONZ) i Unii Europejskiej (UE). Wśród wielu aspektów tego prawa szczególny nacisk kładzie się na kwestię równego traktowania kobiet i mężczyzn w dostępie do zatrudnienia, warunków pracy, awansu oraz dostępu do szkolenia zawodowego.

Kwestia równego traktowania kobiet i mężczyzn od samego początku towarzyszy procesowi integracji europejskiej. Przez długi okres sprawy społeczne, a wśród nich równość kobiet i mężczyzn w zatrudnieniu, postrzegane były jednak wyłącznie w kontekście integracji gospodarczej jako warunek i jednocześnie rezultat powodzenia projektu budowy wspólnego rynku opartego o swobodę przepływu osób, usług i kapitału ${ }^{1}$. Stopniowo punkt ciężkości przesuwał się w kierunku społecznej gospodarki europejskiej. Dużą rolę w tym procesie odegrał Trybunał Sprawiedliwości Unii Europejskiej (TSUE), który podniósł zasadę równego traktowania kobiet i mężczyzn do rangi zasady ogólnej prawa unijnego ${ }^{2}$ oraz dostrzegł społeczny, a nie

1 Zob. M. Weiss, Convergence and/or Divergence in Labour Law Systems: A European Perspective, "Comparative Labour Law \& Policy Journal" 2007, Vol. 29, s. 469. Podporządkowanie spraw społecznych procesowi integracji gospodarczej dobitnie potwierdził TSUE w sprawie C-341/05 Laval i C-348/08 Viking.

2 Zob. orzeczenie TSUE z dnia 15 lipca 1978 roku w sprawie 149/77 Defrenne III [1978] ECR 1365, 1378. 
tylko ekonomiczny aspekt realizacji tej zasady w odniesieniu do kwestii wynagrodzenia $^{3}$. Traktat Amsterdamski ${ }^{4}$ uznał równość kobiet i mężczyzn za jeden z głównych celów Wspólnoty (art. 2 TWE $^{5}$ ), potwierdził, że we wszystkich działaniach Wspólnota dąży do eliminowania nierówności i popierania równości między kobietami i mężczyznami (art. 3 TWE), jak również upoważnił organy Wspólnoty do podjęcia działań zwalczających dyskryminację m.in. z powodu płci ${ }^{6}$. Jednocześnie po raz pierwszy swoją podstawę w prawie pierwotnym uzyskały działania pozytywne zmierzające do wyrównania szans na rynku pracy przedstawicieli płci niedostatecznie reprezentowanej (art. 141 ust. 4 TWE) 7 .

Pomimo zmiany, jaka na przestrzeni ostatnich lat dokonała się w świadomości społecznej na temat pozycji kobiet i mężczyzn w życiu społecznym i zawodowym, kobiety w dalszym ciągu doświadczają przypadków nierównego traktowania. Rynek pracy stanowi istotny obszar, w którym dochodzi do przejawów nierównego traktowania ze względu na płeć ${ }^{8}$. W literaturze zwraca się uwagę na istnienie silnej zależności między przeciwdziałaniem dyskryminacji a wzmocnieniem konkurencyjności europejskiej gospodarki oraz poprawą życia jej obywateli9. Przeciwdziałanie naruszaniu zasady równości kobiet i mężczyzn w zatrudnieniu jest silnie powiązane z realizacją celów unijnej Strategii Europa 2020, wzrostu do 75\% wskaźnika zatrudnienia w UE osób w wieku 20-64 lat oraz zmniejszenia

\footnotetext{
3 Tak w orzeczeniu TSUE z dnia 8 kwietnia 1976 roku w sprawie 43/75 Defrenne II [1976] ECR 00455.

4 Podpisany w dniu 2 października 1997 roku. Wszedł w życie w dniu 1 czerwca 1999 roku (Dz.U. C 340 z 10 listopada 1997 roku).

5 Traktat ustanawiający Wspólnotę Europejską (w brzmieniu nadanym Traktatem z Maastricht z dnia 7 lutego 1992 roku) (Dz.Urz. UE C nr 321E), s. 1. Aktualnie art. 2 Traktatu z o Unii Europejskiej, podpisanego w dniu 7 lutego 1992 roku (Dz.U. C 191 z 29 lipca 1992 roku) stanowi, że UE jest „społeczeństwem opartym na pluralizmie, niedyskryminacji, tolerancji, sprawiedliwości, solidarności oraz na równości kobiet i mężczyzn".

6 Powołane przepisy stanowiły usankcjonowanie orzecznictwa Trybunału Sprawiedliwości Unii Europejskiej (TSUE) w sprawach z zakresu równości płci. Zob. orzeczenia w sprawach: 43/75 Defrenne II [1976] ECR 00455; 4/73, Nold [1974] ECR 491; 136/79 National Panasonic [1980] ECR 2033 44/79; Hauer [1979] ECR 3727.

7 Uprzednio działania pozytywne dopuszczało prawo wtórne, tj. nieobowiązująca już dyrektywa 76/207/EWG z dnia 9 lutego 1976 roku w sprawie wprowadzenia w życie zasady równego traktowania kobiet i mężczyzn w zakresie dostępu do zatrudnienia, kształcenia, awansu zawodowego i warunków pracy (Dz.Urz. WE L nr 39) oraz rekomendacja Rady 84/635/EEC z dnia 13 grudnia 1984 roku w sprawie popierania pozytywnych działań na rzecz kobiet.

8 Kobiety za każdą przepracowaną godzinę nadal zarabiają średnio o $16,4 \%$ mniej od mężczyzn, przy czym zróżnicowanie wynagrodzenia ze względu na płeć waha się w państwach członkowskich od 4,4\% do $27 \%$ i rozbieżność ta na poziomie UE maleje w bardzo powolnym tempie. Zob. European Commission (2014), Tackling the gender pay gap in the European Union, Luxembourg, Publications Office of the European Union.

9 Zob. R. Krauze, Case 54/07 Centrum vgelijkheid van kansen en voor racismebestrijding v. Firma Feryn NV, [2008] ECR I-5187, “Common Market Law Review” 2010, Vol. 3, s. 917-931.
} 
o 20 milionów liczby osób zagrożonych ubóstwem, które mają prowadzić do budowy konkurencyjnej, ale równocześnie spójnej społecznie gospodarki europejskiej $^{10}$. Tym samym zasada równości kobiet i mężczyzn oraz środki jej realizacji nie tylko nie straciły na aktualności, ale w obecnych warunkach społeczno-gospodarczych stały się szczególnie istotne.

W świetle powyższych uwag celem niniejszego artykułu jest przedstawienie problematyki działań pozytywnych ${ }^{11}$ jako instrumentu realizacji zasady równości kobiet i mężczyzn w zatrudnieniu na podstawie ustawodawstwa obowiązującego w UE i w Polsce oraz w oparciu o poglądy doktryny i orzecznictwa. Podjęte rozważania koncentrują się na ukazaniu miejsca działań pozytywnych w obszarze problematyki równości.

\section{DZIAŁANIA POZYTYWNE W USTAWODAWSTWIE UE ORAZ W ŚWIETLE POLSKIEGO PRAWA PRACY}

Po raz pierwszy możliwość podejmowania działań pozytywnych została zagwarantowana w dyrektywie Rady 76/207/EWG z dnia 9 lutego 1976 roku w sprawie wprowadzenia w życie zasady równego traktowania kobiet i mężczyzn w zakresie dostępu do zatrudnienia, kształcenia, awansu zawodowego i warunków pracy, a zatem w okresie, gdy sprawy społeczne we Wspólnocie były wyraźnie podporządkowane integracji gospodarczej. W świetle art. 2 ust. 4 dyrektywy celem działań pozytywnych miało być promowanie równości szans dla kobiet i mężczyzn, w szczególności przez usuwanie istniejących nierówności, które wpływają na szansę kobiet w zakresie dostępu do zatrudnienia, w tym awansu i kształcenia zawodowego oraz warunków pracy. W następstwie podpisania Traktatu Amsterdamskiego działania pozytywne zyskały podstawę w unijnym prawie pierwotnym, w art. 141 ust. 4 TWE. Powołany przepis w niezmienionym kształcie został utrzymany w art. 157 ust. 4 TFUE $^{12}$, w brzmieniu nadanym mu przez Traktat z Lizbony ${ }^{13}$. Na mocy powołanego przepisu państwa członkowskie, w celu zapewnienia pełnej równości między kobietami i mężczyznami w życiu zawodowym, zostały upoważnione do utrzymania lub przyjmowania środków przewidujących specyficzne korzyści,

10 Komunikat Komisji z dnia 3 marca 2010 roku Europa 2020 - Strategia na rzecz inteligentnego i zrównoważonego rozwoju sprzyjającego włączeniu społecznemu, http://ec.europa.eu/ eu2020/pdf/1_PL_ACT_part1_v1.pdf [data dostępu: 16.08.2011].

${ }^{11} \mathrm{~W}$ literaturze działania pozytywne określa się także jako akcje afirmatywne. Na oznaczenie działań pozytywnych używa się również pojęcia „dyskryminacja pozytywna”. Określenie to jest moim zdaniem nietrafne, gdyż nie oddaje istoty działań pozytywnych, a ponadto może prowadzić do błędnego wniosku, że działania pozytywne stanowią odstępstwo od zasady niedyskryminacji.

12 Traktat o funkcjonowaniu Unii Europejskiej z dnia 13 grudnia 2007 roku (Dz.Urz. UE 2012 C 326), s. 1.

13 Traktat z Lizbony z dnia 13 grudnia 2007 roku (Dz.U. C 306 z 17 grudnia 2007 roku). Wszedł w życie 1 grudnia 2009 roku. 
zmierzających do ułatwienia wykonywania działalności zawodowej przez osoby płci niedostatecznie reprezentowanej bądź zapobiegania niekorzystnym sytuacjom w karierze zawodowej i ich kompensowania. Wprawdzie powołany przepis, odmiennie niż art. 2 ust. 4 dyrektywy 76/207/WE, posługuje się neutralnym pojęciem płci niedostatecznie reprezentowane ${ }^{14}$, jednak bez wątpienia działania pozytywne mają w praktyce dużo większe znaczenie dla poprawy pozycji kobiet na rynku pracy. Powyższe potwierdza, w dalszym ciągu aktualna, treść deklaracji nr 28 do Traktatu Amsterdamskiego, zgodnie z którą, przyjmując takie środki, państwa członkowskie powinny mieć na celu przede wszystkim poprawę sytuacji kobiet $\mathrm{w}$ życiu zawodowym ${ }^{15}$. Ponadto szerzej, w porównaniu do regulacji dyrektywy 76/207/WE, określono cel działań pozytywnych, które odtąd miały zmierzać do osiągnięcia faktycznej (materialnej) równości między kobietami i mężczyznami w życiu zawodowym, a nie tylko koncentrować się na kompensowaniu istniejących już nierówności w tym zakresie. Zmiana w podejściu do celu działań pozytywnych była reakcją na orzeczenie TSUE w sprawie C-450/93 Kalanke $^{16}$, w którym Trybunał sformułował podstawowe, w dalszym ciągu aktualne, założenia koncepcji działań pozytywnych. W opinii sporządzonej w tej sprawie adwokat generalny Guiseppe Tesauro wskazał, że formalnie zagwarantowana równość kobiet i mężczyzn pozostanie iluzoryczna, jeżeli nie będzie szła w parze ze środkami, których celem jest zagwarantowanie rzeczywistej (materialnej) równości płci ${ }^{17}$. Późniejsze dyrektywy równościowe uwzględnią tę zmianę. Dyrektywa Rady 54/2006 w zakresie równości płci w art. 3 wskazuje na konieczność zapewnienia w praktyce pełnej równości kobiet i mężczyzn w życiu zawodowym jako podstawy utrzymywania lub przyjmowania przez państwo członkowskie środków w rozumieniu art. 141 ust. 4 traktatu. Wspieranie równości kobiet i mężczyzn jest także celem i zadaniem UE. Na mocy art. 8 TFUE UE została zobligowana do wspierania równości mężczyzn i kobiet we wszystkich swoich działaniach. W doktrynie nie ma zgodności co do charakteru obowiązku nałożonego na UE tym przepisem. Według jednego z poglądów art. 8 TFUE ma moc zasady prawnej, która nie kreuje żadnych indywidualnych uprawnień, ale wyznacza względnie skonkretyzowany obowiązek UE, którego realizacja zależy od konkret-

14 Tak L. Mitrus, Tendencje rozwojowe wspólnotowego prawa pracy, „Państwo i Prawo” 2003, nr 7, s. 33.

15 Deklaracje przyjęte przez Konferencję, http://oide.sejm.gov.pl/oide/images/files/dokumenty/traktaty/Traktat_amsterdamski_PL_16.pdf [data dostępu: 22.12.2014].

16 Orzeczenie TSUE w sprawie C-450/93 Kalanke z dnia 17 października 1995 roku [1995] ECR I-305. W rezultacie art. 2 ust. 4 dyrektywy 76/207/EWG uzyskał nowe brzmienie na mocy dyrektywy Parlamentu Europejskiego i Rady 73/2002/WE z dnia 23 września 2002 roku. Art. 2 ust. 8 w wersji przeredagowanej stanowił, że państwa członkowskie mogą utrzymywać lub przyjmować środki w rozumieniu art. 141 ust. 4 traktatu w celu zapewnienia pełnej równości między mężczyznami i kobietami w praktyce.

17 Kalanke [1996] 1 CEC (CCH) at 219 (Opinion of Advocate General Tesuro). 
nych warunków gospodarczych i społecznych ${ }^{18}$. Karta Praw Podstawowych Unii Europejskiej także nakłada na UE oraz państwa członkowskie obowiązek zapewnienia równości kobiet i mężczyzn we wszystkich dziedzinach, w tym w zakresie wynagrodzenia, pracy i zatrudnienia, stanowiąc o możliwości utrzymywania lub przyjmowania środków zapewniających specyficzne korzyści dla osób płci niedostatecznie reprezentowanej (art. 23). Przyjęta przez polskiego ustawodawcę prawna konstrukcja działań pozytywnych nawiązuje do art. 157 ust. 4 TFUE. Przepis art. $18^{3 \mathrm{~b}} \S 3 \mathrm{k} . p$. definiuje działania pozytywne w kontekście ich celu, jaki stanowi zmniejszenie faktycznych nierówności w zakresie dostępu do zatrudnienia, warunków zatrudnienia, awansów zawodowych, dostępu do szkolenia w celu podnoszenia kwalifikacji zawodowych będących udziałem wszystkich lub znacznej liczby pracowników, ze względu na przyczyny mogące być źródłem nierównego traktowania, wyróżnione w art. $18^{3 \mathrm{a}} \S 1$ k.p. Warto przy tym zauważyć, że polski Trybunał Konstytucyjny już w 1987 roku, a zatem na długo przed formalnym przyjęciem unijnego dorobku prawnego w dziedzinie równości płci, dopuścił możliwość podejmowania działań pozytywnych ${ }^{19}$.

\section{DZIAŁANIA POZYTYWNE A ZASADA RÓWNOŚCI KOBIET I MĘŻCZYZN W ZAKRESIE ZATRUDNIENIA}

Z przeprowadzonych rozważań wynika, że działania pozytywne polegają na czasowym uprzywilejowaniu pewnej grupy osób w celu eliminacji faktycznych nierówności, których osoby te doświadczają w zatrudnieniu ze względu na określoną cechę charakterystyczną, np. płeće ${ }^{20}$.

Wskazuje się, że u podstaw działań pozytywnych leży wzgląd na potrzebę ,rozwiązania zakorzenionych barier napędzających głęboko niekorzystne traktowanie"21 przedstawicieli jednej płci, tzw. płci niedostatecznie reprezentowanej. Działania pozytywne mogą być rozpatrywane w kategoriach środka walki z dyskryminacją i nierównym traktowaniem, jeżeli ich celem jest przeciwdziałanie sytuacji, w której stereotypy i uprzedzenia płciowe, nie zaś rzeczywiste kwalifikacje zawodowe, stanowią jedyne i decydujące kryterium na etapie procesu rekrutacji, awansowania, dostępu

18 A. Wróbel, [w:] Traktat o funkcjonowaniu Unii Europejskiej. Komentarz, pod red. D. Miąsika, N. Półtorak, A. Wróbla, t. 1, Warszawa 2012. Zob. też: orzeczenie TSUE w sprawie C-236/09 Association Belge des Consommateurs Test-Achats ASBL i in. v. Conseil des ministres [2011] ECR I-00773.

19 Zob. orzeczenie Trybunału Konstytucyjnego z dnia 3 marca 1987 roku, P 2/87, OTK 1987, poz. 2.

${ }^{20}$ Zob. A. Śledzińska-Simon, Zasada równości i zasada niedyskryminacji w prawie UE, „Studia BAS” 2011, nr 2(26), s. 69.

${ }_{21}$ M. Bell, L. Waddington, Exploring the Boundaries of Positive Action Under EU Law: A Search for Conceptual Clarity, "Common Market Law Review” 2011, Vol. 5, s. 1503. 
do szkoleń zawodowych oraz ukształtowania warunków pracy, zwłaszcza wysokości wynagrodzenia. W praktyce częściej działania pozytywne mają na względzie poprawę sytuacji na rynku pracy przedstawicieli jednej płci, z reguły kobiet, przez wyrównanie faktycznych nierówności, jakie występują między kobietami i mężczyznami, nawet jeżeli formalnie żadna dyskryminacja czy nierówne traktowanie nie występuje. Różnice w rzeczywistym położeniu na rynku pracy, jakie występują między płciami, dotyczą zasadniczo trzech płaszczyzn: psychofizycznej, społeczno-kulturowej i gospodarczej $^{22}$. W takim przypadku działania pozytywne umożliwiają przedstawicielom płci znajdującej się w niekorzystnej sytuacji zawodowej, w obrębie jednej bądź wszystkich wskazanych płaszczyzn, faktyczny dostęp do praw formalnie im zagwarantowanych w przepisach prawa, na tych samych zasadach co przedstawicielom płci przeciwnej. Uzasadnieniem dla działań pozytywnych jest wówczas przekonanie, że zagwarantowanie równości formalnej nie jest wystarczające do osiągnięcia rzeczywistej równości między kobietami i mężczyznami na rynku pracy.

Działań pozytywnych nie należy rozważać w kategoriach wyjątku czy odstępstwa od zasady równości ${ }^{23}$. Działania pozytywne stanowią formę realizacji, od strony pozytywnej, zasady równości płci, stanowią jej konieczny element ${ }^{24}$. Powyższe znajduje potwierdzenie w treści odpowiednich przepisów prawa unijnego i polskiego, które w zakresie celu działań pozytywnych odwołują się do osiągnięcia „pełnej równości w praktyce”. W pełni istotę działań pozytywnych TSUE wyraził w wyroku w sprawie C-450/93 Kalanke, stwierdzając:

[...] art. 2 ust. 4 dyrektywy (76/207/WE) ma ściśle określony wyłączny cel ograniczający się do zezwolenia na środki, które chociaż pozornie mają charakter dyskryminacyjny - zmierzają $\mathrm{w}$ istocie do usunięcia lub zmniejszenia faktycznych przejawów nierówności mogących występować w danych realiach życia społecznego. Przepis ten dopuszcza zatem regulacje krajowe dotyczące dostępu do pracy, w tym awansu, które przyznając szczególne korzyści kobietom - mają na celu polepszenie ich zdolności do konkurowania na rynku pracy oraz realizacji własnej kariery na równi z mężczyznami ${ }^{25}$.

22 Szerzej na temat przyczyn zróżnicowania pracowników ze względu na płeć zob. M. Rychter-Raj, Uzasadnione zróżnicowanie pracowników ze względu na płeć, „Praca i Zabezpieczenie Społeczne" 2003, nr 8, s. 10. Adwokat Generalny Guiseppe Tesauro w opinii sporządzonej w sprawie Kalanke również zwrócił uwagę na to, że u podstaw istniejących nierówności między kobietami i mężczyznami w życiu zawodowym leży przyjęty model ekonomiczny, społeczny i kulturalny. Zob. Kalanke [1996] 1 CEC (CCH) at 219 (Opinion of Advocate General Tesauro).

${ }_{23}$ Tak też: C. Castello, G. Davies, The Case Law of the Court of Justice in the Field of Sex Equality Since 2000, “Common Market Law Review” 2006, Vol. 43, s. 1567-1616. Zob. także opinię Rzecznika Generalnego Saggio w sprawie C-158/97 Badeck (European Court reports 2000, I-01875, $\S 26$ ). Jedynie art. 23 Karty Praw Podstawowych Unii Europejskiej jest niejednoznaczny, gdy chodzi o określenie działań pozytywnych. Zwrot ,nie stanowi przeszkody” może sugerować, że działania pozytywne stanowią odejście od zasady równości - zob. M. Bell, L. Waddington, op. cit., s. 1503.

24 M. Bell, L. Waddington, op. cit., s. 1503.

25 Por. orzeczenie TSUE w sprawie 312/86 Komisja WE v. Republika Francuska z dnia 25 października 1988 roku, Lex nr 128205. 
Polski Trybunał Konstytucyjny, we wspomnianym już orzeczeniu z dnia 3 marca 1987 roku, także wskazał, że ,przyznanie kobietom dodatkowych uprawnień w porównaniu z mężczyznami ma na celu zagwarantowanie realizacji równouprawnienia, nie przeczy zasadzie równości, ale ją realizuje" ${ }^{26}$. Takie określenie miejsca działań pozytywnych w polityce równości płci jest konsekwencją przyjęcia materialnej, a nie formalnej koncepcji równości. Dużą rolę w tym zakresie odegrał TSUE, konsekwentnie prezentując materialne (pozytywne) podejście do kwestii równości $\mathrm{w} \mathrm{UE}^{27}$.

\section{TSUE WOBEC SYSTEMÓW KWOTOWYCH JAKO FORMY DZIAŁAŃ POZYTYWNYCH W ZAPEWNIENIU FAKTYCZNEJ RÓWNOŚCI KOBIET I MĘŻCZYZN W DOSTĘPIE DO ZATRUDNIENIA}

Najwięcej kontrowersji w praktyce wywołują działania pozytywne polegające na preferowaniu przedstawicieli płci niedostatecznie reprezentowanej w dostępie do zatrudnienia, szkolenia i awansu zawodowego, oparte na zastosowaniu systemów kwotowych, ze względu na cienką granicę, jaka dzieli takie środki od naruszenia zasady równości i niedyskryminacji ${ }^{28}$. TSUE kilkakrotnie rozpatrywał legalność krajowych przepisów prawnych państw członkowskich przyznających priorytet przedstawicielom jednej płci (z reguły kobietom) w dostępie do zatrudnienia. Kluczowe znaczenie mają $\mathrm{w}$ tym zakresie trzy orzeczenia: wspomniane już orzeczenie w sprawie C-450/93 Kalanke oraz orzeczenia w sprawie C-409/95 Marshall $^{29}$ i późniejsze w sprawie C-158/97 Badeck ${ }^{30}$.

W sprawie Kalanke TSUE badał zgodność z unijnym porządkiem prawnym przepisów niemieckiego kraju związkowego Brema przyznających kobietom, mającym takie same kwalifikacje co mężczyźni, pierwszeństwo w dostępie do zatrudnienia w sektorach, w których kobiety są niedoreprezentowane ${ }^{31}$. TSUE,

26 Orzeczenie TSUE z dnia 3 marca 1987 roku, P 2/87, OTK 187/1/2.

27 Zob. orzeczenie TSUE z dnia 10 lipca 2008 roku w sprawie C-54/07 Centrum voor Gelijkheid van Kansen en Racismebestrijding v Firma Feryn NV [2008] ECR I-5187; TSUE z dnia 30 kwietnia 1998 roku w sprawie C-136/95 Caisse nationaled'assurance vieillesse des travailleurs salariés (CNAVTS) v. Eveline Thibault [1998] ECR I-2011.

28 Zob. C. Mik, Wyrównywanie szans, ale nie automatyczne preferowanie, „Rzeczpospolita. Prawo na Co Dzień” 1998, nr 5, s. 13.

${ }^{29}$ Orzeczenie TSUE z dnia 11 listopada 1997 roku Hellmut Marshall v. Land Nordrhein-Westfalen [1997] ECR I-06363.

30 Orzeczenie TSUE z dnia 28 marca 2000 roku w sprawie Georg Badeck i inni [2000] ECR I-01875.

31 Paragraf 4 Bremeńskiego prawa o równym traktowaniu kobiet i mężczyzn w sektorze usług publicznych z dnia 20 listopada 1990 roku stanowił między innymi, że w sytuacji awansu kobieta, która ma takie same kwalifikacje, jak mężczyzna ubiegający się o to samo stanowisko, ma pierwszeństwo w sektorach, które są niedostatecznie reprezentowane przez kobiety, przy czym niedosta- 
nie negując co do zasady działań pozytywnych, za sprzeczne z zasadą niedyskryminacji i równego traktowania uznał regulacje będące przedmiotem oceny $\mathrm{w}$ rozpatrywanej sprawie $\mathrm{w}$ zakresie, $\mathrm{w}$ jakim przyznają kobietom automatyczne, absolutne i bezwarunkowe pierwszeństwo w zatrudnieniu lub awansowaniu jako nieproporcjonalne do celu, jaki ma być osiągnięty przez stosowanie polityki równych szans na rzecz kobiet, w tym także w kontekście integracji ekonomicznej - budowy wspólnego rynku wewnętrznego ${ }^{32}$. W opinii wydanej w toku postępowania w sprawie Adwokat Generalny Tesauro podkreślił, że równość szans zakłada osiągnięcie takiej samej pozycji wyjściowej. Całkowicie ignorując rzeczywiste trudności, jakich kobiety doświadczają na rynku pracy ze względu na istniejące stereotypy i uprzedzenia, Adwokat Generalny błędnie założył, że posiadając te same kwalifikacje, kandydaci znajdowali się w tej samej pozycji wyjściowej, stąd przyznanie w takiej sytuacji kobietom pierwszeństwa zatrudnienia wykracza poza zakres i cel działań pozytywnych. Orzeczenie TSUE w sprawie Kalanke spotkało się z mieszanym przyjęciem w doktrynie prawa pracy. Jako główny zarzut podnoszono brak szczegółowego uzasadnienia stanowiska Trybunału w tak ważnej kwestii, prowadzący do wątpliwości interpretacyjnych odnośnie do rodzaju dopuszczalnych działań pozytywnych, a w konsekwencji do zbyt restrykcyjnego podejścia do tej kwestii ${ }^{33}$. Pomimo tego stanowisko Trybunału w sprawie Kalanke zasadniczo wydaje się być trafne. Nawet przy założeniu różnic w rzeczywistej pozycji na rynku pracy regulacja nakładająca na pracodawcę $\mathrm{w}$ istocie bezwarunkowy obowiązek zatrudnienia kandydata jednej płci jest zbyt daleko idąca. Komisja Europejska, podejmując się interpretacji wskazanego orzeczenia, słusznie wskazała, że zgodne z zasadą równego traktowania i niedyskryminacji są tylko takie systemy kwotowe, które jednocześnie przewidują tzw. klauzulę wyjątku, pozwalającą pracodawcy na odstąpienie od kryterium płci ze względu na inne szczególne okoliczności dotyczące kandydata na dane stanowisko ${ }^{34}$.

Powyższa interpretacja została uwzględniona przez TSUE w kolejnym orzeczeniu w sprawie Marshall ${ }^{35}$, w którym Trybunał wyraźnie odniósł się do klauzuli wyjąt-

teczna reprezentacja kobiet ma miejsce, gdy kobiety nie stanowią co najmniej połowy zatrudnionych w jednostce organizacyjnej, w której znajduje się dane stanowisko.

32 Szeroko orzeczenie to omawia M. Rychter-Raj, op. cit., s. 11-13.

33 L. Senden, Positive Action in the EU Put to the Test. A Negative Score?, "3 Maastricht Journal 146 at $149 " 1996$.

34 Zob. Communication from the Commission to the European Parliament and the Council on the interpretation of the judgment of the Court of Justice on 17 October 1995 in Case C-450/93, Kalanke v Freie Hansestadt Bremen COM/96/88.

35 W orzeczeniu tym TSUE oceniał zgodność art. 2 ust. 4 dyrektywy 76/207/WE $§ 25$ ust. 4 krajowej ustawy o służbie cywilnej z dnia 1 maja 1981 roku, przewidującego pierwszeństwo awansu kobiet na stanowiskach, na których reprezentacja kobiet jest mniejsza, jeżeli kobiety i mężczyźni mają jednakowe kwalifikacje, chyba że szczególne okoliczności przemawiają na korzyść kandydata płci męskiej. 
ku w kontekście zgodności systemów kwotowych jako formy działań pozytywnych z zasadą równości i niedyskryminacji. W negatywnej opinii wydanej w tej sprawie Adwokat Generalny Jacobs wyraźnie nawiązał do stanowiska Adwokata Generalnego Tesauro w sprawie Kalanke, podkreślając, że tak skonstruowana regulacja jest ukierunkowana na osiągnięcie równych rezultatów w zakresie zatrudnienia kobiet i mężczyzn. TSUE nie podzielił tej argumentacji, dostrzegając to, co zostało pominięte w sprawie Kalanke, że regulacje o preferencyjnym charakterze mają w tym przypadku na celu eliminację negatywnych dla kobiet skutków uprzedzeń i stereotypów wpływających na rzeczywiste szanse kobiet na rynku pracy, pomimo pozornie tej samej pozycji wyjściowej. Trybunał tym samym odrzucił błędne założenie towarzyszące opiniom Adwokatów Generalnych w sprawie Kalanke i Marshall, że posiadanie tych samych kwalifikacji przez kandydatów na dane stanowisko jest równoznaczne z posiadaniem przez nich równych szans na zatrudnienie. Powyższego założenia zabrakło w uzasadnieniu do orzeczenia w sprawie Kalanke. Trybunał nie zmienił jednak zdania na temat charakteru regulacji o preferencyjnym charakterze, która nie może automatycznie preferować kandydata jednej płci - niedostatecznie reprezentowanej. W konsekwencji Trybunał pozytywnie ocenił ustawodawstwo krajowe przyznające kobietom, mającym jednakowe kwalifikacje z mężczyznami, pierwszeństwo awansu na stanowiska w służbie publicznej, na których kobiety są niedoreprezentowane, ze względu na to, że regulacje te, odmiennie niż regulacje będące przedmiotem oceny w sprawie Kalanke, przewidują obowiązek przeprowadzenia obiektywnej, indywidualnej oceny obu kandydatur, uwzględniającej wszystkie istotne kryteria i zatrudnienie kandydata płci męskiej, jeżeli choć jedna szczególna okoliczność przemawia na jego korzyść, z zastrzeżeniem, że zastosowane kryteria nie mają charakteru dyskryminującego kobiety, co w szczególności dotyczy kryteriów tzw. dyskryminacji pośredniej. Trybunał nie wskazał jednak, nawet przykładowo, okoliczności, które mogą stanowić podstawę do odstąpienia od pierwszeństwa, pozostawiające ich dookreślenie ustawodawcy i sądom krajowym.

Dużo dalej idące pod tym względem jest orzeczenie TSUE w sprawie $B a$ deck ${ }^{36}$, w którym Trybunał oceniał zgodność z zasadą równego traktowania systemów kwotowych, tzw. flexible quota results i tzw. strict quota results. Znaczenie wskazanego orzeczenia dla problematyki działań pozytywnych wyraża się w tym, że w tej sprawie Trybunał poszedł o krok dalej w zakresie określenia celu oraz granic dopuszczalności stosowania działań pozytywnych. Mając na uwadze zasady uprzednio wypracowane w sprawach Kalanke i Marshall, TSUE zaaprobował system kwotowy - flexible quota results, przewidujący pierwszeństwo zatrudnie-

${ }^{36}$ W orzeczeniu tym TSUE oceniał zgodność art. 2 ust. 4 dyrektywy 76/207/WE prawa landu Hesji o równym traktowaniu kobiet i mężczyzn w zakresie usług publicznych. Szerzej na ten temat zob. K. Küchhold, Badeck - the Third German Reference on Positive Action, "Industrial Law Journal" 2001, Vol. 30, No. 1, s. 116-120. 
nia kobiet w sektorach służby publicznej, w których kobiety są niedoreprezentowane, w sytuacji gdy kandydaci i kandydatki mają jednakowe kwalifikacje, jeżeli jest to konieczne do zapewnienia przestrzegania celów planu awansu kobiet, a nie sprzeciwiają się temu względy większej wagi prawnej, pod warunkiem, że kandydaci są przedmiotem obiektywnej oceny uwzględniającej ich szczególne sytuacje osobiste. Uzasadniając zajęte stanowisko, Trybunał zwrócił uwagę na kwestię, która zdaje się być kluczowa dla określenia istoty działań pozytywnych. Wskazał, że płeć nie może stanowić decydującego kryterium przy wyborze osób do zatrudnienia, jeżeli nie jest to rzeczywiście niezbędne dla poprawy niekorzystnej sytuacji kobiet na rynku pracy. Tok argumentacji TSUE opiera się na założeniu, że niższy w porównaniu do mężczyzn poziom reprezentacji kobiet na określonych stanowiskach czy w konkretnych zawodach nie może automatycznie przesądzać, że taka sytuacja jest efektem uprzedzeń czy stereotypów, jakimi kieruje się pracodawca na etapie rekrutacji. Trybunał wskazał, że okoliczności indywidualne dotyczące kandydatów na dane stanowisko, uzasadniające odstąpienie od kryterium płci, muszą być odpowiednie do wymagań zawodowych związanych z tym stanowiskiem. Powołując się na ustawodawstwo landu Hesji, Trybunał dopuścił przy dokonywaniu tej oceny takie okoliczności (mające w praktyce dużo większe znaczenie dla kobiet), jak umiejętności i doświadczenie zdobyte w związku z opieką nad dzieckiem czy inną osobą wymagającą opieki, staż pracy, wiek czy data ostatniego awansu, równocześnie wykluczając spod tej ceny sytuację rodzinną, dochód partnera, zatrudnienie w niepełnym wymiarze czasu pracy oraz przerwę w kształceniu spowodowaną koniecznością wykonywania obowiązków rodzinnych. Równocześnie w ramach klauzuli wyjątku zidentyfikowano pięć przypadków, które jako względy większej wagi prawnej również uzasadniają odstąpienie od regulacji o preferencyjnym charakterze. Powyższe obejmuje: byłych urzędników, którzy uprzednio zrezygnowali z zatrudnienia z powodu konieczności wykonywania obowiązków rodzinnych bądź z tego powodu podjęli zatrudnienie $\mathrm{w}$ niepełnym wymiarze czasu pracy i aktualnie chcą powrócić do pracy w pełnym wymiarze czasu pracy; byłych żołnierzy, których służba przekroczyła okres obowiązkowej służby wojskowej; osoby niepełnosprawne i długotrwale bezrobotne. Istotne znaczenie ma jednak akceptacja TSUE dla systemów kwotowych - strict quota results, uznanych za ,automatyczne”, a przez to niedopuszczalne, w sprawach Kalanke i Marshall, przyznających co najmniej połowę miejsc na szkolenia zawodowe kobietom w zawodach, w których kobiety nie są dostatecznie reprezentowane. Wątpliwości, jakie wywołała wskazana regulacja wynikały z braku klauzuli wyjątku oraz warunku posiadania jednakowych kwalifikacji przez kandydatów. Pomimo tego TSUE zaakceptował takie rozwiązanie jako instrument realizacji równości szans, dostrzegając, że kobiety znajdują się w mniej korzystnej sytuacji niż mężczyźni w zakresie dostępu do zatrudnienia na stanowiskach, na których wymagane jest posiadanie określonych kwalifikacji 
zawodowych. Dopuszczając takie uregulowanie, TSUE wskazał, że nie ogranicza ono mężczyzn w dostępie do zatrudnienia na tych stanowiskach. Jego celem jest natomiast wzmocnienie pozycji kobiet na rynku pracy na etapie poprzedzającym zatrudnienie. Uczestnictwo w szkoleniu zawodowym daje kobietom szansę zdobycia kwalifikacji niezbędnych do konkurowania na rynku pracy na równych zasadach z mężczyznami. Ponadto, zdaniem TSUE, środki takie odznaczają się pewnym stopniem elastyczności, gdyż przewidują odstąpienie od parytetu w razie braku wystarczającej liczby wniosków pochodzących od kobiet. Powyższe stanowisko Trybunału w części oddaje treść opinii Adwokata Generalnego Tesauro wydanej w toku postępowania w sprawie Kalanke, w której zwrócił uwagę na znaczenie szkolenia zawodowego dla poprawy sytuacji kobiet na rynku pracy.

\section{ZAKOŃCZENIE}

Z rezolucji Parlamentu Europejskiego z dnia 12 marca 2013 roku w sprawie eliminacji stereotypów płciowych dotyczących płci w EU ${ }^{37}$ wynika, że uprzedzenia i stereotypy płciowe, które nadal dotykają rozmaitych aspektów życia społecznego, mają daleko idące implikacje dla rynku pracy. Determinują dostęp kobiet do zatrudnienia, zwłaszcza w zawodach tradycyjnie uznawanych za "męskie” oraz na podstawie umowy o pracę na czas nieokreślony w pełnym wymiarze czasu pracy, szkolenia i awansu zawodowego. To zaś utrwala istniejący już rozdźwięk w poziomie zatrudnienia między kobietami i mężczyznami, co w dłuższej perspektywie czasu prowadzi do większego wśród kobiet ryzyka ubóstwa i wykluczenia społecznego. W tych uwarunkowaniach istotnego znaczenia nabierają instrumenty, które mają na celu poprawę sytuacji na rynku pracy płci niedoreprezentowanej, z reguły kobiet, przez wyrównanie faktycznych nierówności, jakie występują między kobietami i mężczyznami w zakresie zatrudnienia.

Działania pozytywne stanowią formę realizacji, od strony pozytywnej, zasady równości w praktyce. Uznanie legalności działań pozytywnych jest konsekwencją przyjęcia materialnej, a nie formalnej koncepcji zasady równości, która zakłada osiągnięcie faktycznej (rzeczywistej) równości między kobietami i mężczyznami w życiu zawodowym. Działania pozytywne znajdują uzasadnienie w tych przypadkach, w których zagwarantowane w przepisach prawa prawo do równego traktowania kobiet i mężczyzn w dostępie do zatrudnienia jest niewystarczające do osiągnięcia faktycznej równości między kobietami i mężczyznami na rynku pracy, tj. wówczas, gdy rzeczywista pozycja kobiet i mężczyzn na rynku

37 Rezolucja Parlamentu Europejskiego z dnia 12 marca 2013 roku w sprawie eliminacji stereotypów płciowych dotyczących płci w EU, 2012/2116(INI), www.europarl.europa.eu/sides/ getDoc.do?pubRef=-//EP//TEXT+TA+P7-TA-2013-0074+0+DOC+XML+V0//PL [data dostępu: 01.06.2015]. 
pracy, determinowana szeregiem czynników, uniemożliwia przedstawicielom płci niedostatecznie reprezentowanej dostęp do praw formalnie zagwarantowanych im w przepisach prawa.

Regulacje przyznające pierwszeństwo zatrudnienia (awansu) kobiet, oparte na zastosowaniu systemów kwotowych, powinny mieć na celu kompensowanie rzeczywistych nierówności między kobietami i mężczyznami na rynku pracy, będących skutkiem uprzedzeń i stereotypów, jakimi kieruje się pracodawca, nie zaś kreowanie „sztucznych” progów zatrudnienia, które pozostają w sprzeczności z zasadą równości i niedyskryminacji. Pracodawca w każdym przypadku powinien mieć możliwość odstąpienia od regulacji o charakterze preferencyjnym w oparciu o obiektywne okoliczności, które przemawiają na rzecz kandydata płci męskiej. Równocześnie należy podkreślić, że regulacje przewidujące pierwszeństwo zatrudnienia (awansu) kobiet, ze swej istoty ukierunkowane na osiągnięcie określonego „rezultatu” w zakresie poziomu zatrudnienia kobiet, same w sobie nie przyczynią się w dłuższej perspektywie czasu do poprawy zdolności kobiet do konkurowania na rynku pracy na równych zasadach z mężczyznami. Do osiągnięcia tego celu niezbędne są instrumenty, które rzeczywiście będą ukierunkowane na osiągnięcie równości szans kobiet i mężczyzn w zakresie zatrudnienia, tj. takich, które bezpośrednio odnoszą się do czynników leżących u podstaw nierówności między kobietami i mężczyznami na rynku pracy, bez których realizacja zasady równości płci w zakresie zatrudnienia pozostanie pozorna. Do instrumentów takich należą poradnictwo i szkolenie zawodowe oraz działania umożliwiające łatwiejsze godzenie obowiązków rodzinnych i zawodowych. Takie podejście do kwestii działań pozytywnych prezentuje TSUE, który w kolejnych orzeczeniach w sprawie Kalanke, Marshall i Badeck dopuścił i dookreślił zasady stosowania systemów kwotowych, wyraźnie rozróżniając ich poszczególne formy.

\section{BIBLIOGRAFIA}

Bell M., Waddington L., Exploring the Boundaries of Positive Action Under EU Law: A Search for Conceptual Clarity, "Common Market Law Review" 2011, Vol. 5.

Castello C., Davies G., The Case Law of the Court of Justice in the Field of Sex Equality Since 2000, "Common Market Law Review" 2006, Vol. 43.

Communication from the Commission to the European Parliament and the Council on the interpretation of the judgment of the Court of Justice on 17 October 1995 in Case C-450/93, Kalanke v. Freie Hansestadt Bremen COM/96/88.

Deklaracje przyjęte przez Konferencję, http://oide.sejm.gov.pl/oide/images/files/dokumenty/traktaty/Traktat_amsterdamski_PL_16.pdf [data dostępu: 22.12.2014].

Dyrektywa 76/207/EWG z dnia 9 lutego 1976 roku w sprawie wprowadzenia w życie zasady równego traktowania kobiet i mężczyzn w zakresie dostępu do zatrudnienia, kształcenia, awansu zawodowego i warunków pracy (Dz.Urz. WE L nr 39).

European Commission (2014), Tackling the gender pay gap in the European Union, Luxembourg, Publications Office of the European Union. 
Komunikat Komisji z dnia 3 marca 2010 roku Europa 2020 - Strategia na rzecz inteligentnego i zrównoważonego rozwoju sprzyjającego włączeniu społecznemu, http://ec.europa.eu/ eu2020/pdf/1_PL_ACT_part1_v1.pdf [data dostępu: 16.08.2011].

Krauze R., Case 54/07 Centrum vgelijkheid van kansen en voor racismebestrijding v. Firma Feryn NV, [2008] ECR I-5187, "Common Market Law Review” 2010, Vol. 3.

Küchhold K., Badeck - the Third German Reference on Positive Action, "Industrial Law Journal" 2001, Vol. 30, No. 1.

Mik C., Wyrównywanie szans, ale nie automatyczne preferowanie, „Rzeczpospolita. Prawo na Co Dzień" 1998, nr 5.

Mitrus L., Tendencje rozwojowe wspólnotowego prawa pracy, „Państwo i Prawo” 2003, nr 7.

Orzeczenie Trybunału Konstytucyjnego z dnia 3 marca 1987 roku, P 2/87, OTK 1987, poz. 2.

Orzeczenie TSUE w sprawie Nold [1974] ECR 491.

Orzeczenie TSUE w sprawie Hauer [1979] ECR 3727.

Orzeczenie TSUE w sprawie 136/79 National Panasonic [1980] ECR 2033 44/79.

Orzeczenie TSUE w sprawie 312/86 Komisja WE v. Republika Francuska z dnia 25 października 1988 roku, Lex nr 128205.

Orzeczenie TSUE w sprawie C-236/09 Association Belge des Consommateurs Test-Achats ASBL $i$ in. v. Conseil des ministres [2011] ECR I-00773.

Orzeczenie TSUE w sprawie C-450/93 Kalanke z dnia 17 października 1995 roku [1995] ECR I-305.

Orzeczenie TSUE z dnia 8 kwietnia 1976 roku w sprawie 43/75 Defrenne II [1976] ECR 00455.

Orzeczenie TSUE z dnia 15 lipca 1978 roku w sprawie 149/77 Defrenne III [1978] ECR 1365, 1378.

Orzeczenie TSUE z dnia 3 marca 1987 roku, P 2/87, OTK 187/1/2.

Orzeczenie TSUE z dnia 11 listopada 1997 roku Hellmut Marshall v. Land Nordrhein-Westfalen [1997] ECR I-06363.

Orzeczenie TSUE z dnia 30 kwietnia 1998 roku w sprawie C-136/95 Caisse nationaled'assurance vieillesse des travailleurs salariés (CNAVTS) v. Eveline Thibault [1998] ECR I-2011.

Orzeczenie TSUE z dnia 28 marca 2000 roku w sprawie Georg Badeck i inni [2000] ECR I-01875.

Orzeczenie TSUE z dnia 10 lipca 2008 roku w sprawie C-54/07 Centrum voor Gelijkheid van Kansen en Racismebestrijding v. Firma Feryn NV [2008] ECR I-5187.

Rekomendacja Rady 84/635/EEC z dnia 13 grudnia 1984 roku w sprawie popierania pozytywnych działań na rzecz kobiet.

Rezolucja Parlamentu Europejskiego z dnia 12 marca 2013 roku w sprawie eliminacji stereotypów płciowych dotyczących płci w EU, 2012/2116(INI), www.europarl.europa.eu/sides/getDoc. do?pubRef=-//EP//TEXT+TA+P7-TA-2013-0074+0+DOC+XML+V0//PL [data dostępu: 01.06.2015].

Rychter-Raj M., Uzasadnione zróżnicowanie pracowników ze względu na płeć, „Praca i Zabezpieczenie Społeczne" 2003, nr 8.

Senden L., Positive Action in the EU Put to the Test. A Negative Score?, "3 Maastricht Journal 146 at 149" 1996.

Śledzińska-Simon A., Zasada równości i zasada niedyskryminacji w prawie UE, „Studia BAS” 2011, nr 2(26).

Traktat Amsterdamski z dnia 2 października 1997 roku (Dz.U. C 340 z 10 listopada 1997 roku).

Traktat o funkcjonowaniu Unii Europejskiej z dnia 13 grudnia 2007 roku (Dz.Urz. UE 2012 C 326).

Traktat o Unii Europejskiej z dnia 7 lutego 1992 roku (Dz.U. C 191 z 29 lipca 1992 roku).

Traktat ustanawiający Wspólnotę Europejską (w brzmieniu nadanym Traktatem z Maastricht z dnia 7 lutego 1992 roku) (Dz.Urz. UE C nr 321E).

Traktat z Lizbony z dnia 13 grudnia 2007 roku (Dz.U. C 306 z 17 grudnia 2007 roku).

Weiss M., Convergence and/or Divergence in Labour Law Systems: a European Perspective, "Comparative Labour Law \& Policy Journal” 2007, Vol. 29. 
Wróbel A., [w:] Traktat o funkcjonowaniu Unii Europejskiej. Komentarz, pod red. D. Miąsika, N. Półtorak, A. Wróbla, t. 1, Warszawa 2012.

\section{SUMMARY}

Despite the change in the position of women and men in their social and professional life, which has taken place in the social awareness during recent years, women still continue to experience cases of unequal treatment. The labour market is one of the most important areas where the manifestation of unequal treatment based on gender can be noticed. Therefore the principle of equality in employment and the means of its implementation not only haven't lost its importance but become especially significant in the current socio-economical situation. In the light of the foregoing, the purpose of this article is to present the positive actions as an instrument of implementation of the equality principle in employment between women and men under the EU and Polish legislation based on the views of doctrine and jurisprudence. The considerations that have been undertaken focus on showing the place of positive actions in the context of gender equality.

Keywords: labour law; equal treatment; positive action; European Union 